\title{
Influence of different wastewater treatment technologies on genotoxicity and dioxin-like toxicity in effluent-exposed fish
}

\author{
Sabrina Wilhelm ${ }^{1 *}$ (D), Stefanie Jacob ${ }^{1}$, Michael Ziegler ${ }^{1}$, Heinz-R. Köhler ${ }^{1}$ and Rita Triebskorn ${ }^{1,2}$
}

\begin{abstract}
Background: In situ exposure of rainbow trout up- and downstream of differently equipped wastewater treatment plants (WWTPs) and subsequent analyses of micronuclei frequencies and hepatic EROD activities were used to evaluate the impact of the effluents on fish health. Two of the facilities (WWTPs A and B) were conventional treatment plants. WWTP C has been equipped with a powdered activated carbon stage. Here, analyses were conducted prior and subsequent to this upgrade.

Results: Differences did not only occur when comparing conventional (WWTPs A, B and C prior to the upgrade) and advanced treatment (WWTP C after the upgrade), but also between the conventionally equipped WWTPs. There was no indication for genotoxic effects or pollution-related EROD induction in fish exposed at WWTP A. In contrast, trout exposed at WWTP B expressed strong reactions. However, here, adverse reactions were also observed in fish kept upstream. Similar observations were made for EROD activities in fish exposed at WWTP C prior to the upgrade, whereas genotoxic effects could only be seen in trout kept downstream of this effluent. Upgrading of WWTP C resulted in a significant reduction of both genotoxic effects and EROD levels.
\end{abstract}

Conclusions: The results show financial investments in advanced wastewater treatment to be beneficial for aquatic ecosystems, especially when conventional technologies do not sufficiently remove pollutants. Yet, negative impacts of effluents on aquatic organisms can, under certain conditions, also be avoided by conventional treatment. Therefore, we recommend deciding on the necessity and the type of WWTP upgrading on a case-by-case basis.

Keywords: Wastewater, Fish health, Genotoxicity, Micronucleus test, CypIA1, EROD activity

\section{Background}

During the last decade, there has been an increasing public and scientific concern for the presence of micropollutants in the aquatic environment and the possibility of associated negative effects in aquatic organisms [1-4]. Micropollutants, such as ingredients of pharmaceuticals, human care products, pesticides as well as industrial chemicals, are often insufficiently eliminated by conventional wastewater treatment $[5,6]$. Thus, in industrialized countries, wastewater treatment plants (WWTPs) belong to the major sources of organic micropollutants entering

\footnotetext{
*Correspondence: sabrina_wilhelm@live.de

${ }^{1}$ Institute of Evolution and Ecology, Animal Physiological Ecology, University of Tübingen, Tübingen, Germany

Full list of author information is available at the end of the article
}

the aquatic environment [2]. As a consequence, new additional treatment technologies, including activated carbon, ozonation or reverse osmosis, which were shown to have a high capacity for eliminating micropollutants [7-9], have been implemented more frequently in recent years [10].

Up to now, the knowledge on possible advantages of further wastewater treatment for the health of aquatic organisms is still scarce. To close this gap, several case studies were conducted during the last years which proved biological effect monitoring based on biotests and biomarkers to be a useful tool to assess the effluentrelated risk for aquatic organisms [11, 12]. Moreover, comparison of data obtained prior and subsequent to the installation of a new wastewater treatment technology 
[13-18] or of samples taken at different steps within the treatment process $[19,20]$ was shown to be a valuable strategy to evaluate the efficiency of this new technology. Especially in situ exposure (active monitoring) of caged fish has often been applied in this context [21, 22]. Compared to the passive approach, i.e. the capture and examination of feral organisms, active biomonitoring entails several advantages, e.g. knowledge about the exposure period and standardization regarding the age, size and reproductive stage of the exposed individuals. Furthermore, adaptive responses that may result in a desensitization of the organisms' physiological responses can be excluded in active monitoring [21, 23]. Thus, caging of fish can help to control different parameters that might affect the subsequently analyzed biomarkers. The latter are defined as biological responses induced by a chemical or a mixture of chemicals, giving a measure of exposure and/or the toxic effect $[24,25]$. Such biomarkers, such as alterations in biotransformation enzyme levels, the induction of micronuclei and other abnormalities of the blood cell nuclei as well as histopathological reactions, may provide early warning sentinels for deleterious environmental and ecological effects of chemicals [26], and can be used to characterize the impact of WWTP effluents on the health status of aquatic organisms.

In the present study, in situ exposure of rainbow trout (Oncorhynchus mykiss) and subsequent biomarker analyses were used to examine the impact of three different WWTP effluents on the health status of the fish. Two of the investigated facilities were conventional treatment plants, combining mechanical, biological and chemical treatment. The third one, the WWTP Langwiese (Ravensburg, Germany), has been equipped with an additional powdered activated carbon stage in September 2013. To characterize fish health, two biomarkers were analyzed: (1) to reveal genotoxic effects, micronuclei were investigated in peripheral fish blood cells. Micronuclei are formed during cell division due to a failed reintegration of chromosomal fragments or whole chromosomes into the daughter nuclei. Although this may also happen spontaneously, high frequencies of micronuclei are considered indicative for the presence of genotoxic compounds in the water [27, 28]. (2) As a second biomarker, alterations in the level of the biotransformation enzyme CYPIA1 (cytochrome P450IA1) were measured by the EROD (ethoxyresorufin-O-deethylase) assay. CYPIA1 is mainly present in liver tissue and is involved in the detoxification of numerous endogenous and exogenous compounds [29]. Previous studies showed high induction of EROD activity in fish after exposure to organic compounds, including dioxin-like substances, polycyclic aromatic hydrocarbons or structurally related chemicals such as several pharmaceuticals and pesticides [29-31]. Thus, high levels of CYPIA1 and, consequently, high EROD levels can be used as an indicator for exposure to such organic substances $[29,32]$.

\section{Methods \\ Study sites}

Due to agreements with the operators to anonymize the obtained results, the two conventional treatment plants under investigation are subsequently referred to as WWTP A and B. For consistency, the third facility, the WWTP Langwiese, is further called WWTP C.

Both conventional facilities (WWTP A and B) are located at tributaries of the Neckar River near Tübingen, Southern Germany. Treatment in these WWTPs combines primary, secondary and tertiary processes, including screening, primary sedimentation, activated sludge, denitrification, nitrification, phosphorus removal, and secondary sedimentation. WWTP A is designed for wastewater treatment of 115,000 population equivalents and treats mainly domestic and, in small parts, industrial wastewater. The catchment area of the receiving water comprises $130 \mathrm{~km}^{2}$ and is mainly characterized by agricultural and, to a smaller extent, by urban use. WWTP B treats the wastewater of approximately 140,000 population equivalents. Wastewater treated by this facility is of domestic and industrial origin. It discharges into a river with a catchment area of $140 \mathrm{~km}^{2}$ which is characterized by agriculture and urban impact. Compared to the receiving river of WWTP A, the proportion of urbanized area in the catchment and the proportion of industrial wastewater received by WWTP B are much higher [33].

The third WWTP under investigation was the WWTP Langwiese (AZV Mariatal, Ravensburg). It is designed for wastewater treatment of 170,000 population equivalents and receives mainly domestic wastewater. The WWTP discharges treated water into the river Schussen, an important tributary of Lake Constance. The catchment area of this river is densely populated and in large parts used for agricultural activities. Before September 2013, treatment in this WWTP combined processes comparable to the conventional treatment described above, however, with subsequent sand filtration. In September 2013, an additional powdered activated carbon stage was installed right before the sand filtration unit. In the framework of the research project SchussenAktivplus, this upgrade and its effects on the ecosystem of the receiving river Schussen was examined in a multi-annual study [34]. In the present study, data concerning the impact of the WWTP upgrade on genotoxic effects and biotransformation in caged rainbow trout are presented. 


\section{Fish origin}

One-year-old rainbow trout (Oncorhynchus mykiss) were provided by the fish farm Lohmühle (Alpirsbach, Germany). Here, fish are kept in clean water consisting of a mixture of spring water with drinking water quality and stream water originating in a water protection area. The breeding facility is subject to regular controls and rated as category I, disease free [35]. Since the breeder supplies animals for fishery restocking campaigns in German streams, the chosen variety is considered robust and close to feral forms.

\section{Exposure experiments}

Fish were exposed in cages of $60 \times 100 \times 50 \mathrm{~cm}$ (described in detail by Vincze et al. [36], 20-21 individuals per cage) located 50-200 m upstream and directly downstream of the effluent in the respective river. The cages downstream were placed in the rivers to receive a mixture of approximately 50\% effluent and 50\% river water. Fish were fed every 2 days with equal amounts of food provided by the hatchery.

Rainbow trout serving as controls were dissected directly at the fish hatchery. Fish serving as controls regarding the exposure at WWTP C prior to the upgrade were kept in aquaria installed in climate chambers at the University of Tübingen at $8{ }^{\circ} \mathrm{C}$ and a $12 / 12 \mathrm{~h}$ light cycle. However, due to the poor growth of these fish, we switched to hatchery controls in all following exposure periods. Detailed information about exposure times is given in Table 1.

\section{Sampling}

Fish were euthanized with an overdose of tricaine methanesulfonate (MS-222, Sigma-Aldrich, St. Louis, USA; $1 \mathrm{~g} / \mathrm{L}$, buffered with $\mathrm{NaHCO}_{3}$ ) and sacrificed by spine-cut prior to dissection.

\section{Analyses of genotoxic effects: micronucleus test}

Blood samples were collected with a pipette immediately after spine-cut. After transmission to microscopic slides (two per fish, previously cleaned with $99 \%$ ethanol), the slides were air-dried for $2 \mathrm{~min}$ and fixed in methanol for $1 \mathrm{~min}$. Subsequently, they were stained with $50 \%$ Giemsa solution for $4 \mathrm{~min}$, followed by washing steps in tap and distilled water. 2000 erythrocytes per individual were inspected under a light microscope (Zeiss Axiostar plus) with regard to the presence of micronuclei according to Rocha et al. [37].

\section{Analyses of the CYPIA1 activity in liver: EROD assay}

Liver tissue (one quarter of the entire organ) was dissected immediately after spine-cut and directly frozen in liquid nitrogen. CYPIA1 activity was determined by the EROD assay with the CYPIA1 EROD activity kit from Ikzus Environment (Alessandria, Italy) adjusted to 96-well-plate format. According to the kit manual, tissue samples were homogenized in ice-cold extraction buffer. The homogenate was centrifuged for $20 \mathrm{~min}$ at $9000 \mathrm{rcf}$ and $4{ }^{\circ} \mathrm{C}$, and the obtained supernatant was stored at $-80{ }^{\circ} \mathrm{C}$ until further processing. Protein content was determined according to Bradford [38] using BSA as standard. To determine the EROD activity in each liver sample, fluorescence $\left(\lambda_{\mathrm{ex}}=520 \mathrm{~nm} ; \lambda_{\mathrm{em}}=590 \mathrm{~nm}\right)$ was measured for $10 \mathrm{~min}$ using a microplate fluorescence reader (FLx800, Biotek Instruments). Each sample was analyzed in duplicates and EROD activity was determined as pmol resorufin produced per minute and $\mathrm{mg}$ protein $(\mathrm{pmol} / \mathrm{mg} \times \mathrm{min})$.

\section{Statistics}

Statistical analyses were exclusively conducted with data relative to the respective control (for fish exposed at WWTP A: hatchery control sampled on 06 May 2015; for fish exposed at WWTP B: hatchery control

Table 1 Exposure periods

\begin{tabular}{lllll}
\hline Test system & Type of exposure & Start of exposure & End of exposure (date of sampling) & Duration of exposure \\
\hline WWTP A & Cages $^{\text {a }}$ & 27 Feb 2015 & $17 \mathrm{Apr} 2015$ & 50 days \\
& Hatchery control $^{*}$ & & $06 \mathrm{May} 2015$ & Immediate dissection \\
WWTP B & Cages $^{\text {b }}$ & 03 Mar 2016 & $15 \mathrm{Mar} 2016$ & 13 days \\
& Hatchery control & & $03 \mathrm{Mar} 2016$ & Immediate dissection \\
WWTP C & Cages & 15 Nov 2012 (prior to upgrade)/02 & 17 Jan 2013 (prior to upgrade)/04 Feb & 63 days (prior to upgrade)/64 days \\
& & Dec 2013 (after upgrade)/03 Dec & 2014 (after upgrade)/05 Feb 2015 & (after upgrade)/64 days (after \\
& & 2014 (after upgrade) & (after upgrade) & upgrade)
\end{tabular}

\footnotetext{
${ }^{a}$ Exposure at WWTP A was terminated after 50 days due to rising water temperatures and falling water levels downstream of the effluent

${ }^{b}$ Exposure at WWTP B was terminated after 13 days due to the incidence of mortality at Day 11
} 
sampled on 03 March 2016; for fish exposed at WWTP $\mathrm{C}$ prior to the upgrade: laboratory controls sampled on 24 January 2013; for fish exposed at WWTP C subsequent to the upgrade: hatchery controls sampled on 29 January 2014 and on 04 February 2015). To simplify comparison between the datasets, control values were set to $100 \%$. All tests were run in R [39]. Results were checked for normal distribution and homoscedasticity, using Shapiro-Wilk and Fligner-Killeen test. If necessary, data were sqrt-transformed. Due to previously reported sex-related differences in CYPIA1 activity [40, 41], results of EROD assays were first tested for a possible impact of sex using the $l m$-function. Since no significant effects could be found, data for female and male fish were pooled. Data sets for WWTPs A and B were analyzed using ANOVA with Tukey HSD post hoc tests with a significance level of 0.05 . Data sets for WWTP C were analyzed using either ANOVA with pairwise comparisons (lsmeans package, [42]) or Kruskal-Wallis test with pairwise Wilcoxon tests (agricolae package, [43]), both followed by correction for multiple testing according to Holm [44].

\section{Results}

\section{Genotoxic effects}

Average micronuclei frequencies detected in exposed and control fish are presented in Table 2.

Regarding WWTP A, fish exposed in cages displayed lower numbers of micronuclei than control individuals (Fig. 1a). In contrast, three to fourfold higher frequencies could be detected in blood cells of rainbow trout exposed in cages at WWTP B (Fig. 1b). Similarly, erythrocytes of fish exposed downstream of the WWTP C prior to the installation of the additional activated carbon stage contained significantly higher relative numbers of micronuclei than blood cells of controls and fish exposed upstream. Subsequent to the WWTP upgrade, a significant reduction in the number of micronuclei could be observed in trout exposed downstream of this effluent (Fig. 1c).

\section{CYPIA1 activity}

Data regarding the EROD activities in fish exposed at WWTP $\mathrm{C}$ have, in parts, already been published by Maier et al. [45]. In the present study, these data were complemented with results obtained subsequent to the WWTP upgrade.

Average EROD activities of exposed and control rainbow trout are presented in Table 3. Since basal EROD activities were shown to vary widely, e.g. between laboratories, even within the same species $[29,46]$, the discussion is based on values relative to the respective control fish.

No significant differences between the relative hepatic EROD activities of control fish and fish exposed in cages at WWTP A could be detected. In addition, no differences between results for the upstream and downstream sites could be found (Fig. 2a). As for genotoxicity, rainbow trout exposed at WWTP B showed a different reaction pattern (Fig. 2b): upstream of the WWTP B, enzyme levels in fish livers were on average two times higher than control levels. On contrary, fish exposed in the cage downstream of the effluent expressed EROD activity levels that were in the same range as control levels. At WWTP C prior to the WWTP upgrade, a significantly elevated EROD activity was detected in livers of fish exposed in the cages. Subsequent to the upgrade, lower values were observed at both exposure sites. However, this reduction was much more pronounced in fish exposed downstream of the WWTP effluent (Fig. 2c).

\section{Discussion}

In general, we could detect a high variation in micronuclei rates and in EROD activities when comparing the different controls of the three exposures. This variation was probably caused by the fact that the exposures were conducted in different years. Hence, different breeding cohorts, which might have been raised under different temperature conditions, were used, resulting in different micronuclei and EROD activity baselines. However, the high micronuclei frequencies in control fish of the exposure at WWTP A and the higher EROD activity in control fish regarding WWTP $\mathrm{C}$ were still in the range

Table 2 Frequencies of micronuclei (\%o, means \pm standard deviations) in peripheral blood of exposed and control fish

\begin{tabular}{llll}
\hline & \multicolumn{3}{l}{ Erythrocytes with micronuclei (\%o), mean \pm standard deviation } \\
\cline { 2 - 4 } & Upstream of WWTP & Downstream of WWTP & \multicolumn{1}{c}{ Control } \\
\hline WWTP A & $0.55 \pm 0.51$ & $0.29 \pm 0.30$ & $1.23 \pm 0.89$ \\
WWTP B & $1.47 \pm 1.02$ & $1.81 \pm 1.21$ & $0.35 \pm 0.45$ \\
WWTP C & & & $0.81 \pm 0.24$ \\
Prior to WWTP upgrade & $1.10 \pm 0.49$ & $2.30 \pm 1.50$ & $0.35 \pm 0.34$ \\
Subsequent to WWTP upgrade & $0.29 \pm 0.42$ & $0.45 \pm 0.50$ & \\
\hline
\end{tabular}


a WWTP A

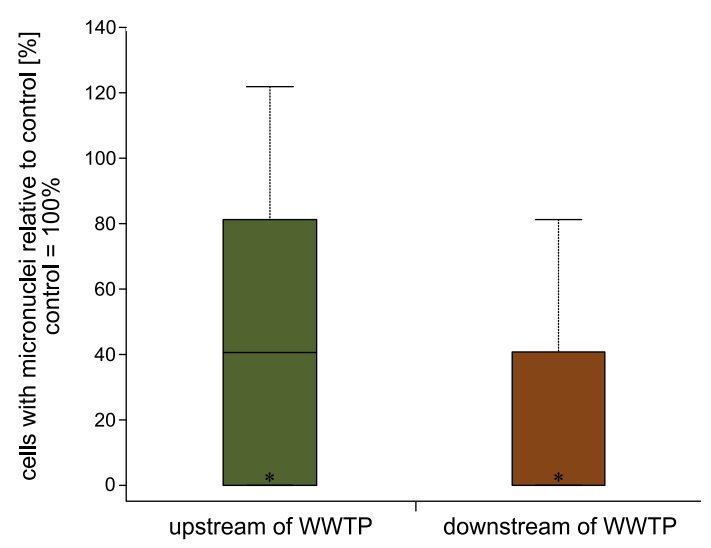

C WWTP C

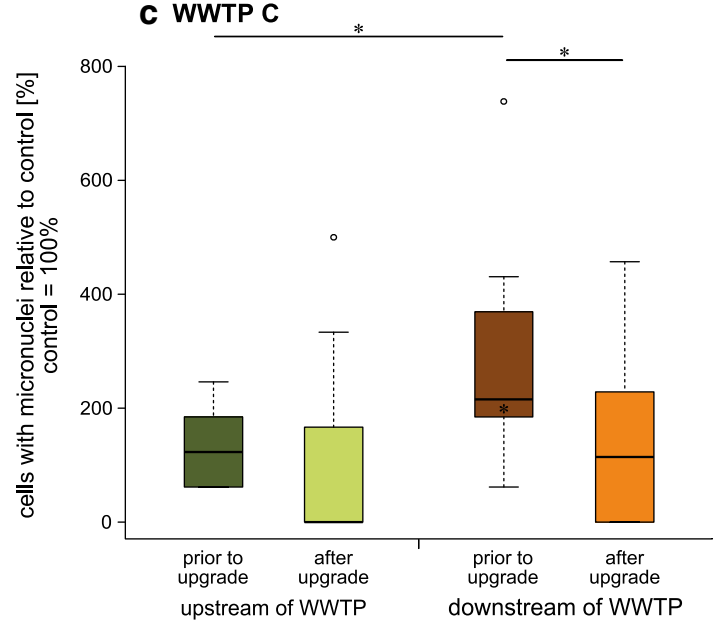

b WWTP B

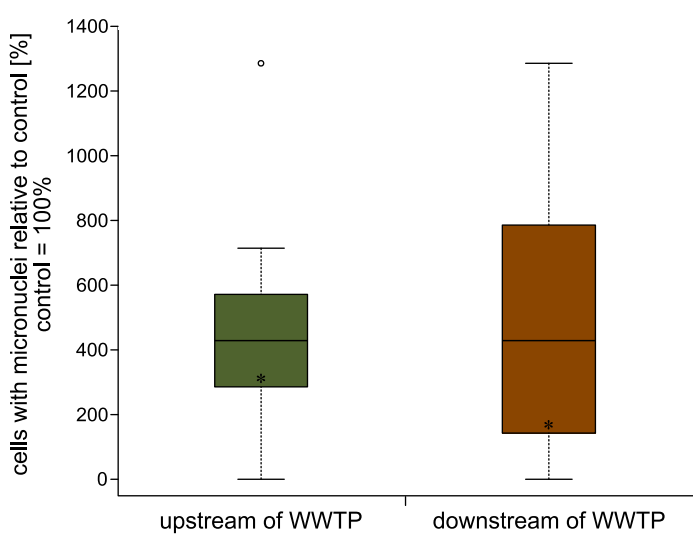

Fig. 1 Micronuclei frequencies [\%] in rainbow trout exposed up- and downstream of different WWTPs. Frequencies are given relative to respective control levels. Latter were set to $100 \%$. Bold lines within boxes display the median values, boxes the $25-75 \%$ quantiles, whiskers the minimum and maximum values, circles potential outliers. Sample sizes: a WWTP A: upstream: $n=19$ and downstream: $n=17 ; \mathbf{b}$ WWTP B: upstream: $n=18$ and downstream: $n=16$; cWWTP C: prior to WWTP upgrade: upstream: $n=10$ and downstream: $n=10$, subsequent to WWTP upgrade: upstream: $n=26$ and downstream: $n=31$. Asterisks and horizontal lines indicate significant differences between exposure sites, asterisks within boxes indicate significant differences to the respective controls. a WWTP A: ANOVA, $F(2,46)=9.20, p=0.0004$; Tukey HSD: upstream vs. control: $p=0.0086$; downstream vs. control: $p=0.0003$. b WWTP B: ANOVA(sqrt), F(2,51)=15.18, $p<0.0001$; Tukey HSD: upstream vs. control: $p=0.0002$; downstream vs. control: $p<0.0001$. cWWTP C: prior to upgrade: Kruskal(sqrt), $\mathrm{Chi}^{2}(2)=9.61, p=0.0080, a^{\prime}=0.0125 /$ upstream vs. downstream: pairwise comparison, $p=0.0200, a^{\prime}=0.0167$ and downstream vs. control: pairwise comparison, $p=0.0013, a^{\prime}=0.0100$. Downstream/prior vs. subsequent to WWTP upgrade: Kruskal, $\operatorname{Chi}^{2}(1)=6.49, p=0.0109, a^{\prime}=0.0250$

Table 3 EROD activities (pmol/min*mg, means \pm standard deviations) in livers of exposed and control fish

\begin{tabular}{llll}
\hline & \multicolumn{3}{l}{ EROD activity $(\mathbf{p m o l} / \mathbf{m i n} * \mathbf{m g})$ mean \pm standard deviation } \\
\cline { 2 - 4 } & Upstream of WWTP & Downstream of WWTP & Control \\
\hline WWTP A & $0.71 \pm 0.56$ & $1.09 \pm 1.36$ & $0.63 \pm 0.30$ \\
WWTP B & $0.48 \pm 0.22$ & $0.25 \pm 0.17$ & $0.23 \pm 0.17$ \\
WWTP C & & & $0.44 \pm 0.69$ \\
Prior to WWTP upgrade & $1.57 \pm 1.47$ & $4.90 \pm 4.52$ & $1.05 \pm 1.43$ \\
Subsequent to WWTP upgrade & $1.19 \pm 1.22$ & $1.29 \pm 1.09$ & \\
\hline
\end{tabular}


a WWTP A

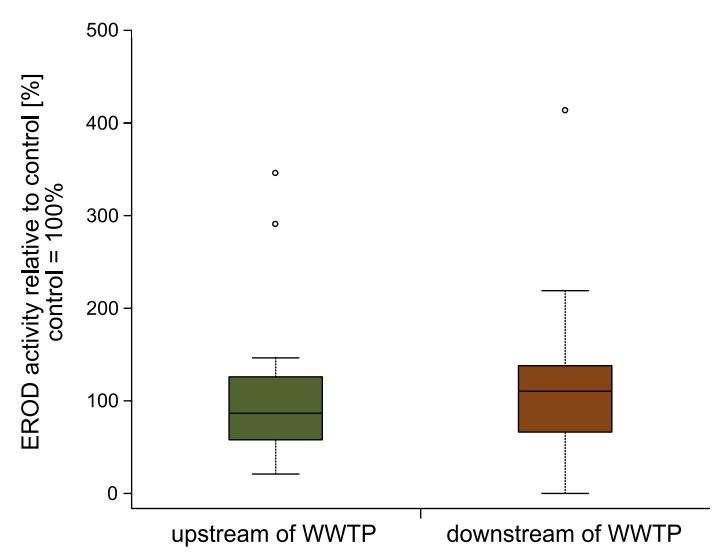

C WWTP C

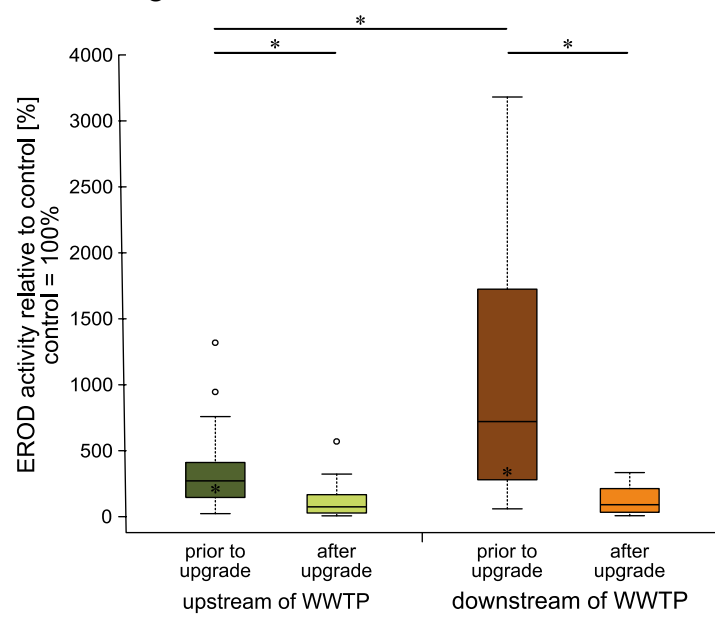

b WWTP B

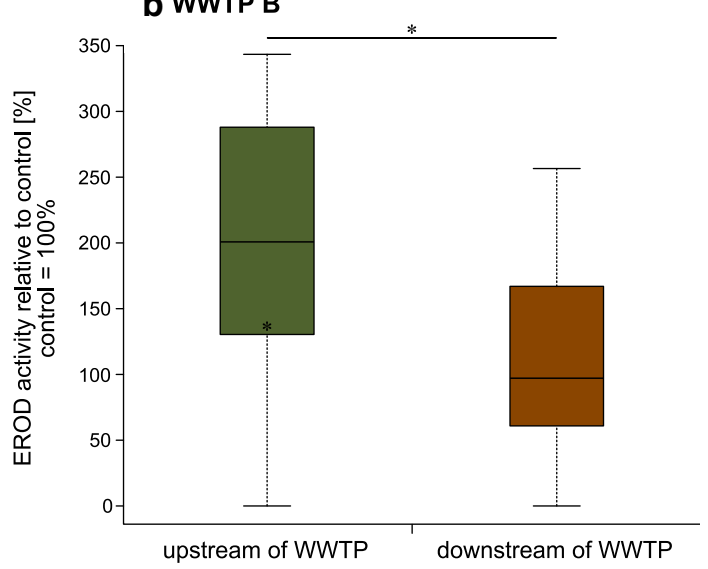

Fig. 2 Relative hepatic EROD activity [\%] in rainbow trout exposed up- and downstream of different WWTPs. Frequencies are given relative to respective control levels. Latter were set to $100 \%$. Bold lines within boxes display the median values, boxes the $25-75 \%$ quantiles, whiskers the minimum and maximum values, circles potential outliers. Sample sizes: a WWTP A: upstream: $n=15$ and downstream: $n=17 ; \mathbf{b}$ WWTP B: upstream: $n=16$ and downstream: $n=15$. cWWTP C: prior to WWTP upgrade: upstream: $n=17$ and downstream: $n=11$, subsequent to WWTP upgrade: upstream: $n=38$ and downstream: $n=41$. Asterisks and horizontal lines indicate significant differences between exposure sites; asterisks within boxes indicate significant differences to the respective controls. a WWTP A: ANOVA(sqrt), F(2,40)=0.61, $p=0.5490$. $\mathbf{b}$ WWTP B: ANOVA(sqrt), $\mathrm{F}(2,56)=5.64, p=0.0059$; Tukey HSD: upstream vs. control: $p=0.0142$; downstream vs. control: $p=0.0394$. cWWTP C: prior to upgrade: ANOVA(sqrt), $F(2,35)=10.06, p=0.0004, a^{\prime}=0.0250 /$ upstream vs. control: pairwise comparison, $p=0.0490, a^{\prime}=0.0500$, downstream vs. control: pairwise comparison, $p=0.0001, a^{\prime}=0.0125$ and upstream vs. downstream: pairwise comparison, $p=0.0061, a^{\prime}=0.0250$. Upstream/prior vs. subsequent to WWTP upgrade: ANOVA(sqrt), F(1,53)=17.31, $p=0.0001, a^{\prime}=0.0170$. Downstream/prior vs. subsequent to WWTP upgrade: ANOVA(sqrt), $F(1,50)=44.57 ; p<0.0001, a^{\prime}=0.0100$

of control levels published previously $[27-29,46]$. Nevertheless, due to the high variations in baseline levels and to relate the health state of fish exposed in the cages to the one of unexposed fish that were sampled at the same time and that were comparable regarding age, reproductive state (as shown by histological analyses of gonads), and origin, we decided to base our discussion on relative micronuclei rates and EROD activities.

When comparing the three WWTPs investigated in the present study, differences regarding genotoxic effects and
EROD activities occurred between the conventionally equipped WWTPs, which might have been caused by differences in the composition of wastewater received by the WWTPs as well as by different general background pollution levels in the connected rivers. Thus, micronuclei frequencies detected in fish exposed at WWTP A as well as in respective controls were in the same range as in control fish of the same age examined in previous studies [47, 48], indicating rather a spontaneous micronuclei induction than an induction caused by genotoxic compounds. 
In addition, there was no evidence for exposure to substances inducing CYPIA1 in these fish. On the contrary, rainbow trout exposed at WWTP B and WWTP C prior to the upgrade showed strong reactions. Thus, significantly elevated relative micronuclei frequencies could be detected in blood cells of these fish. A comparable induction of micronuclei has already been observed previously in studies examining the potential hazardous effects of WWTP effluents on aquatic organisms. Hence, Ergene et al. [49] observed a two to threefold increase in micronuclei frequencies in Oreochromis niloticus after 6 days of exposure to water samples of a river receiving industrial and municipal wastewater. Batista et al. [50] detected, compared to control fish, a threefold increase in Tilapia rendalli and a twofold increase in Hoplias malabaricus caught at a site characterized by a contribution of domestic sewage. Furthermore, Liney et al. [51] observed a significantly elevated level of micronuclei in blood of juvenile roach (Rutilus rutilus) exposed for 300 days to diluted wastewater from a conventional treatment plant. Thus, the observed micronuclei induction in fish exposed downstream of WWTP B and C might have, at least in parts, been caused by genotoxic compounds that were not completely eliminated from the effluent. Chemical analyses of effluent samples of WWTP B (conducted by the Kompetenzzentrum Spurenstoffe BadenWürttemberg, Stuttgart, Germany, unpublished data) and of WWTP C prior to the upgrade (conducted within the framework of the BMBF project SchussenAktivplus [34]) did not reveal excessively high concentrations of a particular substance that might explain the strong effects observed in the exposed fish. However, diclofenac, a pharmaceutical found in both effluents, was shown to induce genotoxicity in Danio rerio at very low concentrations that were in the same range as the ones detected in the effluents of the present study [52]. In addition, this substance induced DNA damage in Daphnia magna after $48 \mathrm{~h}$ [53]. Ibuprofen, which is also often found in WWTP effluents, induced micronuclei formation in Oreochromis niloticus after $48 \mathrm{~h}$ exposure $[54,55]$. Regarding WWTP $\mathrm{B}$, the chemical analyses also revealed a periodically elevated concentration of the polycyclic musk HHCB, which was shown to possess genotoxic potential [56]. However, concerning WWTP B, significantly elevated micronucleus frequencies were also observed in rainbow trout exposed upstream of the effluent indicating a general background contamination of the river, which might have resulted from diffuse inputs as well as from other WWTPs located upstream of the exposure sites. In addition, heavy rainfall events occurred during the exposure. Consequently, untreated water discharged by storm water overflow basins located upstream of the exposure sites might also have contributed to the background pollution upstream of the WWTP, as previously described by Launay et al. [57]. The absence of differences between the upand downstream sites at WWTP B could be due to the short exposure time of only 13 days. It is possible that a stronger effect of the effluent on the micronucleus induction might have become visible with prolonged exposure, since a pronounced negative impact of the WWTP effluent on fish health was indicated by an incidence of mortality at the site downstream of this WWTP, after only 11 days of exposure.

To interpret the results of the conducted EROD assays, the reaction kinetics of the CYPIA1 induction has to be taken into account: Accordingly, low enzyme activities do not only occur in the absence of inducing substances, but also as a result of severe cellular destruction [29]. Histopathological analyses of liver samples of exactly those individuals that have been exposed downstream of WWTP B revealed severe reactions and destructive alterations (see Additional file 1) which could explain the low EROD levels detected. In fact, inhibition of EROD activity with increasing pollutant concentrations, probably as a result of overstrained or pathologically damaged biotransformation processes has been described in the past $[12,58]$. Known mediators of the CYPIA1 enzyme are polycyclic aromatic hydrocarbons, polycyclic biphenyls [29] as well as structurally related compounds, such as different pesticides and pharmaceuticals [30, 31, 59]. For example, the anti-inflammatory diclofenac and the polycyclic musk HHCB, which were also detected in the effluents examined in the present study, induced EROD activity in the microsomal fractions of various deep-sea fish species, including Trachyrynchus scabrus, Mora moro, Cataetix laticeps, and Alepocephalus rostratus [60]. Furthermore, effects of wastewater on EROD levels in fish have already been observed in a number of previous studies. Thus, McCallum et al. [61] detected an up to threefold increase in dioxin-like toxicity in round goby (Neogobius melanostomus) exposed for 28 days to wastewater discharged by a secondary WWTP. DíazGarduño et al. [62] have also observed an approximately 3.2-fold increase of the CYPIA1 induction in Senegalese sole (Solea senegalensis) after 7 days of exposure to urban wastewater. Studies examining feral gudgeons have revealed increased EROD activities in liver tissue of fish caught downstream of a WWTP [63].

However, as for genotoxicity, elevated EROD levels were also detected in rainbow trout exposed upstream of the WWTP B, again indicating a general background pollution of the river caused by diffuse inputs as well as by WWTPs and stormwater overflows located upstream of the exposure site. Nevertheless, the incidence of mortality observed at the downstream site after a short exposure period of only 11 days and the 
results of other biomarker analyses, e.g. histological analyses of kidney and liver (see Additional file 1), indicated a strong negative impact of WWTP B on the fish health status. Non-target screening of this effluent conducted by the Zweckverband Landeswasserversorgung (Langenau, Germany; unpublished data) revealed periodically high levels of the substance Hallcomid M-810. This surfactant was shown to affect rainbow trout survival and had a LD50 of $21.1 \mathrm{mg} / \mathrm{L}$ in an acute $96-\mathrm{h}$ toxicity test [64]. Although the exact concentration of this substance in the effluent of WWTP B was not quantified, the signal obtained suggested a level in the low $\mathrm{mg} / \mathrm{L}$ range.

In addition to differences detected between fish exposed at equally equipped WWTP, differences could also be detected when comparing conventional and advanced wastewater treatment. Hence, a significant reduction in the micronuclei frequency was observed in trout exposed downstream of the effluent of WWTP C subsequent to the upgrade with an additional powdered activated carbon stage. The low micronuclei frequencies that were still present in control fish and in caged trout at this time were in the same range as control values detected in previous studies in fish of comparable age and size $[65,66]$, indicating a spontaneous micronuclei induction in these fish. Chemical analyses conducted within the framework of the project SchussenAktivplus revealed a general reduction of micropollutants in effluent and surface water samples downstream of the WWTP Langwiese subsequent to the installation of the powdered activated carbon stage [34]. Accordingly, the reduction in genotoxicity observed in rainbow trout exposed downstream of WWTP C can plausibly be associated with the reduction of genotoxic compounds resulting from advanced wastewater treatment. A comparable reduction of genotoxic potentials by powdered activated carbon was detected by Stalter et al. [67]. Regarding EROD activities, a reduction was observed at both exposure sites, however, it was much more pronounced in fish exposed downstream of the WWTP effluent. As with the decrease in genotoxic effects, the reduction in hepatic EROD activity detected in the present study is plausibly resulting from the improved elimination of CYPIA1-inducing chemicals by the additional powdered activated carbon stage. This interpretation is also supported by in vitro reporter gene assays conducted within the framework of SchussenAktivplus [34, 45], which showed a pronounced reduction of dioxin-like activity in effluent samples of the WWTP Langwiese after the upgrade. A comparable reduction of CYPIA1 induction in rainbow trout resulting from advanced wastewater treatment with granular activated carbon was also observed by Beijer [19].

\section{Conclusion}

In the present study, in situ exposure of rainbow trout with subsequent analyses of micronucleus frequencies and hepatic EROD activities proved to be a suitable tool to investigate effects of differently treated effluents on fish health.

With respect to the discussion on the necessity of advanced purification steps in wastewater treatment, we draw the following conclusions from our study:

1. Whether or not an effluent negatively affects fish health in a river downstream of a WWTP does not only depend on the extension stage of the wastewater treatment technology, but to a high extent also on the composition of the raw wastewater and the surface water quality upstream of the WWTP, which both depend on the characteristics of the catchment area. This could clearly be shown by the different levels of genotoxicity and dioxin-like toxicity found in fish exposed up- and downstream of the three conventionally equipped WWTPs A, B and C prior to its upgrade.

2. Financial investment in additional wastewater treatment, e.g. on the basis of powdered activated carbon as realized at WWTP $C$, is profitable for aquatic ecosystems in cases in which pollutants are not sufficiently removed by conventional technologies, particularly if the upstream situation of the receiving water is rather intact.

\section{Additional files}

Additional file 1: Semi-quantitative histolopathological assessment of liver, kidney and gill samples of fish exposed up- and downstream of WWTP B. Samples were classified into five categories described in detail by Wilhelm et al. [17] according to the symptoms displayed. Shortly, class 1 includes samples in control state, class 2 has been assigned to tissue samples displaying slight reactions, class 3 to samples with pronounced reactions, class 4 describes samples expressing beginning destructive alterations and class 5 has been assigned to liver samples with severe cellular destruction. Asterisks and horizontal lines indicate significant differences between two datasets according to likelihood ratio chi-square tests with subsequent Holm correction.

Additional file 2. All data.

\section{Abbreviations}

WWTP: wastewater treatment plant; EROD: ethoxyresorufin-O-deethylase; CyplA1: cytochrome P450IA1.

\section{Authors' contributions}

SW exposed and sampled trout, carried out biomarker analyses, performed statistical analyses, and prepared the manuscript. SJ exposed and sampled trout and carried out biomarker analyses. MZ exposed and sampled trout and carried out biomarker analyses. HK participated in the design of the study and critically revised the manuscript. RT designed the study and critically revised the manuscript. All authors read and approved the final manuscript. 


\section{Author details}

${ }^{1}$ Institute of Evolution and Ecology, Animal Physiological Ecology, University of Tübingen, Tübingen, Germany. ${ }^{2}$ Steinbeis Transfer-Center for Ecotoxicology and Ecophysiology, Rottenburg, Germany.

\section{Acknowledgements}

The authors would like to thank the staff of all the wastewater treatment plants for cooperation, and the present and past staff members of the Animal Physiological Ecology Section, University of Tübingen, who have been involved in these projects for their support in the field and in the laboratory: Andreas Dieterich, Anja Henneberg, Stefanie Krais, Carla Lorenz, Diana Maier, Katharina Peschke, Hannah Schmieg, Simon Schwarz, Mona Schweizer, Paul Thellmann and Krisztina Vincze.

\section{Competing interests}

The authors declare that they have no competing interests.

\section{Availability of data and materials}

The datasets supporting the conclusions of this article are included within the article and its Additional file 2.

\section{Consent for publication}

Not applicable.

\section{Ethics approval and consent to participate}

All experiments were conducted in strict accordance with German legislation and approved by the animal welfare authority of the Regional Council Tübingen (Regierungspräsidium Tübingen) under Permit Numbers ZO 1/09, ZP $1 / 12$ and ZO 1/15.

\section{Funding}

Funding for the examination of the two conventional wastewater treatment plants was provided by the urban drainage authority (Stadtenwässerung) Reutlingen and the association for sewage treatment (Abwasserverband) Steinlach-Wiesaz.

Results regarding the wastewater treatment plant Langwiese in Ravensburg were collected within the framework of the research project SchussenAktivplus. This project was part of the German Federal Ministry for Education and Research action plan "Sustainable water management (NaWaM)" and integrated in the frame program "Research for sustainable development FONA" (Contract period: 1/2012 to 12/2014, Funding Number 02WRS1281A). Further funding was provided by the foundation "Nature and Environment" of the Regional State Bank Baden-Württemberg (LBBW), the Ministry for Environment, Climate Protection and the Energy sector Baden-Württemberg (Funding Number 371-2014), Jedele \& Partner GmbH Stuttgart, Ökonsult GbR Stuttgart, the municipality of Ravensburg and the associations for sewage treatment AZV Mariatal and AV Unteres Schussental.

Furthermore, we acknowledge support by the Deutsche Forschungsgemeinschaft and Open Access Publishing Fund of the University of Tübingen.

\section{Publisher's Note}

Springer Nature remains neutral with regard to jurisdictional claims in published maps and institutional affiliations.

Received: 23 March 2018 Accepted: 20 June 2018

Published online: 24 July 2018

\section{References}

1. Luo Y, Guo W, Ngo HH, Nghiem LD, Hai Fl, Zhang J, Liang S, Wang XC (2014) A review on the occurrence of micropollutants in the aquatic environment and their fate and removal during wastewater treatment. Sci Total Environ 473-474:619-641. https://doi.org/10.1016/j.scito tenv.2013.12.065

2. Schwarzenbach RP, Escher BI, Fenner K, Hofstetter TB, Johnson CA, von Gunten U, Wehrli B (2006) The challenge of micropollutants in aquatic systems. Science 313:1072-1077. https://doi.org/10.1126/science.11272 91
3. Arslan M, Ullah I, Müller JA, Shahid N, Afzal M (2017) Organic micropollutants in the environment: ecotoxicity potential and methods for remediation. In: Anjum NA, Gill SS, Tuteja N (eds) Enhancing cleanup of environmental pollutants, vol 1. Biological approaches. Springer, Cham, pp 65-99

4. Gavrilescu M, Demnerova K, Aamand J, Agathos S, Fava F (2015) Emerging pollutants in the environment: present and future challenges in biomonitoring, ecological risks and bioremediation. N Biotechnol 32:147-156. https://doi.org/10.1016/j.nbt.2014.01.001

5. Falas P, Wick A, Castronovo S, Habermacher J, Ternes TA, Joss A (2016) Tracing the limits of organic micropollutant removal in biological wastewater treatment. Water Res 95:240-249. https://doi.org/10.1016/j.watre s.2016.03.009

6. Margot J, Rossi L, Barry DA, Holliger C (2015) A review of the fate of micropollutants in wastewater treatment plants. Wiley Interdiscip Rev Water 2:457-487. https://doi.org/10.1002/wat2.1090

7. Gabet-Giraud V, Miège C, Choubert JM, Ruel SM, Coquery M (2010) Occurrence and removal of estrogens and beta blockers by various processes in wastewater treatment plants. Sci Total Environ 408:4257-4269. https://doi.org/10.1016/j.scitotenv.2010.05.023

8. Knopp G, Prasse C, Ternes TA, Cornel P (2016) Elimination of micropollutants and transformation products from a wastewater treatment plant effluent through pilot scale ozonation followed by various activated carbon and biological filters. Water Res 100:580-592. https://doi. org/10.1016/j.watres.2016.04.069

9. Bourgin M, Beck B, Boehler M, Borowska E, Fleiner J, Salhi E, Teichler R, von Gunten U, Siegrist H, McArdell CS (2018) Evaluation of a full-scale wastewater treatment plant upgraded with ozonation and biological post-treatments: abatement of micropollutants, formation of transformation products and oxidation by-products. Water Res 129:486-498. https:// doi.org/10.1016/j.watres.2017.10.036

10. Eggen RIL, Hollender J, Joss A, Schärer M, Stamm C (2014) Reducing the discharge of micropollutants in the aquatic environment: the benefits of upgrading wastewater treatment plants. Environ Sci Technol 48:76837689. https://doi.org/10.1021/es500907n

11. Magdeburg A, Stalter D, Schlusener M, Ternes T, Oehlmann J (2014) Evaluating the efficiency of advanced wastewater treatment: target analysis of organic contaminants and (geno-)toxicity assessment tell a different story. Water Res 50:35-47. https://doi.org/10.1016/j.watres.2013.11.041

12. Hoeger B, van den Heuvel MR, Hitzfeld BC, Dietrich DR (2004) Effects of treated sewage effluent on immune function in rainbow trout (Oncorhynchus mykiss). Aquat Toxicol 70:345-355. https://doi.org/10.1016/j. aquatox.2004.10.010

13. Thellmann P, Greiner-Perth K, Jacob S, Knoll M, Schäfer M, Stängle M, Ziegler M, Scheurer M, Köhler HR, Triebskorn R (2017) Does waste water treatment plant upgrading with powdered activated carbon result in reduced water and sediment toxicity of the receiving stream? Int Water Wastewater Treat. https://doi.org/10.16966/2381-5299.141

14. Henneberg A, Triebskorn R (2015) Efficiency of advanced wastewater treatment technologies for the reduction of hormonal activity in effluents and connected surface water bodies by means of vitellogenin analyses in rainbow trout (Oncorhynchus mykiss) and brown trout (Salmo trutta f fario). Environ Sci Eur 27:22. https://doi.org/10.1186/s12302-015-0056-3

15. Giebner S, Ostermann S, Straskraba S, Oetken M, Oehlmann J, Wagner M (2016) Effectivity of advanced wastewater treatment: reduction of in vitro endocrine activity and mutagenicity but not of in vivo reproductive toxicity. Environ Sci Pollut Res. https://doi.org/10.1007/s11356-016-7540-1

16. Peschke K, Burmester J, Hermann M, Köhler H-R, Reitter K, Scheurer M, Wurm K, Triebskorn R (2016) Reaktionen von Flohkrebsen und Makrozoobenthos auf die Nachrüstung einer Kläranlage mit einer Pulveraktivkohlestufe. gwf-Wasser/Abwasser 157:370-379

17. Wilhelm S, Henneberg A, Köhler HR, Rault M, Richter D, Scheurer M, Suchail S, Triebskorn R (2017) Does wastewater treatment plant upgrading with activated carbon result in an improvement of fish health? Aquat Toxicol 192:184-197. https://doi.org/10.1016/j.aquatox.2017.09.017

18. Hicks KA, Fuzzen ML, McCann EK, Arlos MJ, Bragg LM, Kleywegt S, Tetreault GR, McMaster ME, Servos MR (2017) Reduction of intersex in a wild fish population in response to major municipal wastewater treatment plant upgrades. Environ Sci Technol 51:1811-1819. https://doi. org/10.1021/acs.est.6b05370 
19. Beijer K, Björlenius B, Shaik S, Lindberg RH, Brunström B, Brandt I (2017) Removal of pharmaceuticals and unspecified contaminants in sewage treatment effluents by activated carbon filtration and ozonation: evaluation using biomarker responses and chemical analysis. Chemosphere 176:342-351. https://doi.org/10.1016/j.chemosphere.2017.02.127

20. Stalter D, Magdeburg A, Weil M, Knacker T, Oehlmann J (2010) Toxication or detoxication? In vivo toxicity assessment of ozonation as advanced wastewater treatment with the rainbow trout. Water Res 44:439-448. https://doi.org/10.1016/j.watres.2009.07.025

21. Vieira CED, Costa PG, Cabrera LC, Primel EG, Fillmann G, Bianchini A, dos Reis Bueno, Martinez C (2017) A comparative approach using biomarkers in feral and caged neotropical fish: implications for biomonitoring freshwater ecosystems in agricultural areas. Sci Total Environ 586:598-609. https://doi.org/10.1016/j.scitotenv.2017.02.026

22. Camargo MMP, Martinez CBR (2007) Histopathology of gills, kidney and liver of a neotropical fish caged in an urban stream. Neotrop Ichthyol 5:327-336. https://doi.org/10.1590/S1679-62252007000300013

23. Smolders R, Bervoets $L$, Wepener V, Blust R (2003) A conceptual framework for using mussels as biomonitors in whole effluent toxicity. Hum Ecol Risk Assess 9:741-760. https://doi.org/10.1080/713609965

24. Peakall DB, Walker CH (1994) The role of biomarkers in environmental assessment (3). Vertebrates. Ecotoxicology 3:173-179. https://doi. org/10.1007/BF00117082

25. Depledge MH, Fossi MC (1994) The role of biomarkers in environmental assessment (2). Invertebrates. Ecotoxicology 3:161-172. https://doi. org/10.1007/bf00117081

26. Walker CH (1995) Biochemical biomarkers in ecotoxicology-some recent developments. Sci Total Environ 171:189-195. https://doi. org/10.1016/0048-9697(95)04720-6

27. Al-Sabti K, Metcalfe CD (1995) Fish micronuclei for assessing genotoxicity in water. Mutat Res Toxicol 343:121-135. https://doi.org/10.1016/01651218(95)90078-0

28. Bolognesi C, Hayashi M (2011) Micronucleus assay in aquatic animals. Mutagenesis 26:205-213. https://doi.org/10.1093/mutage/geq073

29. Whyte JJ, Jung RE, Schmitt CJ, Tillitt DE (2000) Ethoxyresorufin-O-deethylase (EROD) activity in fish as a biomarker of chemical exposure. Crit Rev Toxicol 30:347-570. https://doi.org/10.1080/10408440091159239

30. Burkina V, Zlabek V, Zamaratskaia G (2015) Effects of pharmaceuticals present in aquatic environment on phase I metabolism in fish. Environ Toxicol Pharmacol 40:430-444. https://doi.org/10.1016/j.etap.2015.07.016

31. Fernandez C, Carbonell G, Babin M (2013) Effects of individual and a mixture of pharmaceuticals and personal-care products on cytotoxicity, EROD activity and ROS production in a rainbow trout gonadal cell line (RTG-2). J Appl Toxicol 33:1203-1212. https://doi.org/10.1002/jat.2752

32. Gagnon MM, Rawson CA (2017) Bioindicator species for EROD activity measurements: a review with Australian fish as a case study. Ecol Indic 73:166-180. https://doi.org/10.1016/j.ecolind.2016.09.015

33. Schwientek M, Rugner H, Beckingham B, Kuch B, Grathwohl P (2013) Integrated monitoring of particle associated transport of PAHs in contrasting catchments. Environ Pollut 172:155-162. https://doi.org/10.1016/j.envpo I.2012.09.004

34. Triebskorn R (ed) (2017) Weitergehende Abwasserreinigung: Ein wirksames und bezahlbares Instrument zur Verminderung von Spurenstoffen und Keimen im Wasserkreislauf-gemeinsamer Schlussbericht der vom Bundesministerium für Bildung und Forschung sowie vom Ministerium für Umwelt, Klima und Energiewirtschaft Baden-Würrtemberg geförderten Projekte SchussenAktiv, SchussenAktivplus und SchussenAktivplus+. Universitätsbibliothek Tübingen, Tübingen

35. EU (2006) Council Directive 2006/88/EC

36. Vincze K, Scheil V, Kuch B, Köhler HR, Triebskorn R (2015) Impact of wastewater on fish health: a case study at the Neckar River (Southern Germany) using biomarkers in caged brown trout as assessment tools. Environ Sci Pollut Res 22:11822-11839. https://doi.org/10.1007/s11356-015-4398-6

37. Rocha PS, Luvizotto GL, Kosmehl T, Böttcher M, Storch V, Braunbeck T, Hollert H (2009) Sediment genotoxicity in the Tietê River (São Paulo, Brazil): in vitro comet assay versus in situ micronucleus assay studies. Ecotoxico Environ Saf 72:1842-1848. https://doi.org/10.1016/j.ecoenv.2009.04.013

38. Bradford MM (1976) A rapid and sensitive method for the quantitation of microgram quantities of protein utilizing the principle of protein-dye binding. Anal Biochem 72:248-254
39. R Core Team (2015) R: A language and environment for statistical computing. R Foundation for Statistical Computing, Vienna, Austria.http:// www.R-project.org/

40. Sleiderink HM, Oostingh I, Goksøyr A, Boon JP (1995) Sensitivity of cytochrome P450 1A induction in dab (Limanda limanda) of different age and sex as a biomarker for environmental contaminants in the southern North Sea. Arch Environ Contam Toxicol 28:423-430. https:// doi.org/10.1007/bf00211623

41. Larsen HE, Celander M, Goksøyr A (1992) The cytochrome P450 system of Atlantic salmon (Salmo salar): II. Variations in hepatic catalytic activities and isozyme patterns during an annual reproductive cycle. Fish Physiol Biochem 10:291-301. https://doi.org/10.1007/BF00004478

42. Lenth RV (2016) Least-squares means: the R package Ismeans. J Stat Softw 69:1-33. https://doi.org/10.18637/jss.v069.i01

43. de Mendiburu F (2015) agricolae: statistical procedures for agricultural research. R package version 1.2-3. http://cran.r-project.org/packa ge=agricolae

44. Holm S (1979) A simple sequentially rejective multiple test procedure. Scand J Stat 6:65-70

45. Maier D, Benisek M, Blaha L, Dondero F, Giesy JP, Köhler HR, Richter D, Scheurer M, Triebskorn R (2016) Reduction of dioxin-like toxicity in effluents by additional wastewater treatment and related effects in fish. Ecotoxicol Environ Saf 132:47-58. https://doi.org/10.1016/j.ecoen v.2016.04.036

46. Oris JT, Roberts AP (2007) Statistical analysis of cytochrome P4501A biomarker measurements in fish. Environ Toxicol Chem 26(8):1742-1750. https://doi.org/10.1897/07-039R.1

47. Kim IY, Hyun CK (2006) Comparative evaluation of the alkaline comet assay with the micronucleus test for genotoxicity monitoring using aquatic organisms. Ecotoxicol Environ Saf 64:288-297. https://doi. org/10.1016/j.ecoenv.2005.05.019

48. Ǩehulka J, Minařík B, Machala M (2016) Effects of exposure to three environmental chemicals on the selected biochemical parameters of the blood plasma of rainbow trout, Oncorhynchus mykiss (Walbaum). Acta Musei Silesiae Sci Nat 65:15-32. https://doi.org/10.1515/cszma $-2016-0002$

49. Ergene S, Çavaş T, Çelik A, Köleli N, Aymak C (2007) Evaluation of river water genotoxicity using the piscine micronucleus test. Environ Mol Mutagen 48:421-429. https://doi.org/10.1002/em.20291

50. Batista NJC, de CarvalhoMeloCavalcante AA, de Oliveira MG, Medeiros ECN, Machado JL, Evangelista SR, Dias JF, dos Santos CEIl, Duarte A, da Silva FR, da Silva J (2016) Genotoxic and mutagenic evaluation of water samples from a river under the influence of different anthropogenic activities. Chemosphere 164:134-141. https://doi.org/10.1016/j.chemo sphere.2016.08.091

51. Liney KE, Hagger JA, Tyler CR, Depledge MH, Galloway TS, Jobling S (2006) Health effects in fish of long-term exposure to effluents from wastewater treatment works. Environ Heal Perspect 114(Suppl):81-89. https://doi. org/10.1289/ehp.8058

52. Rocco L, Izzo A, Zito G, Peluso C, Stingo V (2011) Genotoxicity in zebrafish (Danio rerio) exposed to two pharmacological products from an impacted Italian river. J Environ Anal Toxicol 1:103. https://doi. org/10.4172/2161-0525.1000103

53. Gómez-Oliván LM, Galar-Martinez M, García-Medina S, Valdés-Alanis A (2014) Genotoxic response and oxidative stress induced by diclofenac, ibuprofen and naproxen in Daphnia magna. Drug Chem Toxicol 37:391-399

54. Ragugnetti M, Adams ML, Guimarães ATB, Sponchiado G, de Vasconcelos EC, de Oliveira CMR (2011) Ibuprofen genotoxicity in aquatic environment: an experimental model using Oreochromis niloticus. Water Air Soil Pollut 218:361-364. https://doi.org/10.1007/s11270-010-0698-0

55. Tixier C, Singer HP, Oellers S, Müller SR (2003) Occurrence and fate of carbamazepine, clofibric acid, diclofenac, ibuprofen, ketoprofen, and naproxen in surface waters. Environ Sci Technol 37:1061-1068. https:// doi.org/10.1021/es025834r

56. Parolini M, Magni S, Traversi I, Villa S, Finizio A, Binelli A (2015) Environmentally relevant concentrations of galaxolide $(\mathrm{HHCB})$ and tonalide (AHTN) induced oxidative and genetic damage in Dreissena polymorpha. J Hazard Mater 285:1-10. https://doi.org/10.1016/j.jhazmat.2014.11.037

57. Launay MA, Dittmer U, Steinmetz H (2016) Organic micropollutants discharged by combined sewer overflows - characterisation of pollutant 
sources and stormwater-related processes. Water Res 104:82-92. https:// doi.org/10.1016/j.watres.2016.07.068

58. Beijer K, Abrahamson A, Brunström B, Brandt I (2010) CYP1A inhibition in fish gill filaments: a novel assay applied on pharmaceuticals and other chemicals. Aquat Toxicol 96:145-150. https://doi.org/10.1016/j.aquat ox.2009.10.018

59. Laville N, Ait-Aissa S, Gomez E, Casellas C, Porcher JM (2004) Effects of human pharmaceuticals on cytotoxicity, EROD activity and ROS production in fish hepatocytes. Toxicology 196:41-55. https://doi.org/10.1016/j. tox.2003.11.002

60. Ribalta C, Solé M (2014) In vitro interaction of emerging contaminants with the cytochrome P450 system of mediterranean deep-sea fish. Environ Sci Technol 48(20):12327-12335. https://doi.org/10.1021/es5029603

61. McCallum ES, Krutzelmann E, Brodin T, Fick J, Sundelin A, Balshine S (2017) Exposure to wastewater effluent affects fish behaviour and tissue-specific uptake of pharmaceuticals. Sci Total Env 605-606:578-588. https://doi. org/10.1016/j.scitotenv.2017.06.073

62. Díaz-Garduño B, Perales JA, Biel-Maeso M, Pintado-Herrera MG, Lara-Martin PA, Garrido-Pérez C, Martín-Díaz ML (2018) Biochemical responses of Solea senegalensis after continuous flow exposure to urban effluents. Sci Total Environ 615:486-497. https://doi.org/10.1016/j.scito tenv.2017.09.304
63. Faller P, Kobler B, Peter A, Sumpter JP, Burkhardt-Holm P (2003) Stress status of gudgeon (Gobio gobio) from rivers in Switzerland with and without input of sewage treatment plant effluent. Environ Toxicol Chem 22:2063-2072. https://doi.org/10.1897/02-356

64. Dorgerloh, M. (1993). Hallcomid M-8-10-acute toxicity to rainbow trout (Oncorhynchus mykiss) in a static test. Unpublished study performed and sponsored by Bayer AG, Leverkmen, Germany and submitted by The C.P. Hall Company, Chicago, IL. Study No. E 280 0720-9. https://www3.epa. gov/pesticides/chem_search/cleared_reviews/csr_PC-99999_9-Jun03_b.pdf. Accessed 14 June 2018

65. Ayllon F, Garcia-Vazquez E (2001) Micronuclei and other nuclear lesions as genotoxicity indicators in rainbow trout (Oncorhynchus mykiss). Ecotoxicol Environ Saf 49:221-225. https://doi.org/10.1006/eesa.2001.2065

66. Marlasca MJ, Sanpera C, Riva MC, Sala R, Crespo S (1998) Hepatic alterations and introduction of micronuclei in rainbow trout (Oncorhynchus mykiss) exposed to a textile industry effluent. Histol Histopathol 13:703-712

67. Stalter D, Magdeburg A, OehImann J (2010) Comparative toxicity assessment of ozone and activated carbon treated sewage effluents using an in vivo test battery. Water Res 44:2610-2620. https://doi.org/10.1016/j. watres.2010.01.023

\section{Submit your manuscript to a SpringerOpen ${ }^{\circ}$ journal and benefit from:}

- Convenient online submission

$\checkmark$ Rigorous peer review

- Open access: articles freely available online

- High visibility within the field

- Retaining the copyright to your article

Submit your next manuscript at $\boldsymbol{\nabla}$ springeropen.com 